\title{
Hezârfen Bir Şair Şânîzâde Mehmed Atâullâh Divan'1 ve Bir Gazelin Şerhi
}

\author{
A Polymath Poet Şânîzâde Mehmed Atâullâh, His Divan and \\ A Ghazel's Interpretation
}

\section{Vildan S. Coşkun}

\section{Öz}

Hezârfen bir şair olan Şânîzâde Mehmed Atâullâh Efendi, daha çok tıp alanındaki eserleri ve meşhur tarihi ile tanınmıştır. Bununla birlikte birden çok sanatla ilgilenmiş ve Divan ortaya koymuş bir şahsiyettir. Pek çok Osmanlı şairi gibi o da şairliğiyle mesleklerini (müderrislik, hekimlik, vak'anüvislik) birlikte yürütmüş, ilmî yönünü sanat ve şiirle taçlandırmıştır. Buna karşılık, Şânîzâde edebî yönünü ele alan çalışmaların sayısı ne yazık ki hem çok az hem de eski tarihli kalmıştır. Bu makalede klasik edebiyatın son döneminde yetişmiş olup pek çok alanda kalem oynatmış Şânîzâde Mehmed Atâullâh Efendi'nin yegâne edebî eseri olan Divan'1 ve bu eseri üzerinden onun az bilinen şairlik yönü üzerinde durulacaktır. Şânîzâde'nin, şiirlerindeki adıyla Atânın Divan'ındaki şiirlerde nelerden ve nasıl bahsettiği incelenecek ve bunlara dayanarak onun yaşadığı asırda ve klasik Türk edebiyatı geleneğindeki yeri anlaşılmaya çalışılacak ve Şânîzâde'nin bir gazeli şerhedilecektir. Divan'ının tenkitli metni (Çipiloğlu, 2005) üzerinden yapılan ve gerektikçe tenkitli metnin dayandığı yazmaya da başvurarak ortaya koyulan bu çalışmayla, Şânîzâde'nin edebî yönüne vurgu yapılmış ve bir gazelinin şerhiyle klasik edebiyat tarihinde gözden uzak kalmış varlığı yeniden ortaya konulmuştur.

Anahtar Kelimeler: Şânîzâde Mehmed Atâullâh Efendi, Divan, 19. Yüzyıl, Klasik Türk Edebiyatı

Doç. Dr., Sakarya Üniversitesi Türk Dili ve Edebiyatı Bölümü Öğretim Üyesi. E-posta: vcoskun@sakarya.edu.tr, ORCID NO: 0000-0002-47781719

$\mathrm{Bu}$ makale iThenticate sistemi tarafından taranmıştır.

Makale Gönderim Tarihi: 25 Şubat 2020. 


\begin{abstract}
Şânîzâde Mehmed Atâullâh Efendi, who was a multi-science scholar, was mostly known for his works in medicine and his famous history book. However, he also became interested in more than one art and he revealed a Divan. Same as many Ottoman poets, he conducted his poetic side together with his professions (professorship, medicine, historiographer and etc.) and at the same time, he crowned his scientific aspect with art and poetry. On the other hand, the sources about Şânîzâde did not mention much about his poethood and there are very few studies on his Divan. In this article, Divan, the only literary work of Şanîzâde Mehmed Atâullâh Efendi, and his less known poetical aspects will be discussed. What and how he talks about in his verses will be examined and a ghazel from his Divan will be annotated. By this work, done through the critical text of Şanîzâde Divan (Çipiloğlu, 2005), and with referring to manuscript that text is based on, we aimed at revising his literary aspect and reminding his existence has been out of sight in the history of classical literature with a ghazel interpretation from his Divan.
\end{abstract}

Keywords: Şânîzâde Mehmed Atâullâh Efendi, Divan, 19th century, Classical Turkish Literature. 


\section{Giriş}

Şânîzâde Mehmed Atâullâh Efendi, meşhur tarih eseri Târîh-i Şânîzâde (Haz. Ziya Yılmazer, I-II, İstanbul 2008), sayesinde literatürde daha çok 19. yüzyıl tarihçileri arasında anılmış, şairliği ise arka planda kalmıştır. Dönemin tezkireleri gibi önemli kaynaklarda bile Şânîzâde'nin Divan'ıyla ilgili bilgiler yeterli görünmemektedir (Bkz. Çipiloğlu, 2005: 15). Ayrıca hakkındaki kaynaklar oldukça sınırlı ve de eski tarihlidir. Oysa yakından bakıldığında Şânîzâde, müderrislik, hekimlik, vak'anüvislik gibi mesleklerin yanında aynı zamanda 19. yüzyılın ilim ve sanatını kendinde toplamayı başarmış çok yönlü ve velut bir şairdir. Bu bakımdan, Divan'ı üzerinde yapılacak yeni çalışmalar, onun az görünen şairliğini "görünür" bir kimliğe dönüştürmeye yardımcı olacaktır. Bu noktadan hareketle, makalemizde klasik Türk edebiyatının son ve zor döneminde yaşamış olup dönemin etkisinin yanı sıra kendi gayretleriyle hezârfen bir kişilik olarak yetişen Şânîzâde Mehmed Atâullâh'ın (Atâ) edebî yönü incelenecektir. Çalışmamız, Adviye Rabia Çipiloğlu'nun yüksek lisans tezi olarak hazırladı̆̆1 Şânîzâde Atâullâh'ın Divan'ı üzerinden yapılmış olup söz konusu tez Şânîzâde hakkında bilinen en kapsamlı çalışmadır (Şânîzâde Atâullâh ve Divan'ı, Boğaziçi Üniversitesi Sosyal Bilimler Enstitüsü Yayımlanmamış Yüksek Lisans Tezi, 2005). Çalışmada önce Divan, okundu. Vezin ve manalarda fark edilen uyumsuzluklarda aynı çalışmanın arkasında yer alan yazmaya müracaat edildi. Daha sonra metin, klasik edebiyattaki üslup ve dil özellikleri açısından incelendi. Muhtevası üzerinde durularak Divan' da işlenen konular, ön plana çıkan kavram ve dil ögeleri (atasözü ve deyim) sıraland1. Son olarak Divan'dan seçilen bir gazelin şerhi yapıldı. Divan'ının yeniden incelenmesiyle Şânîzâde' nin şairlik yönü daha da ön plana çıkartılmış, edebi yönüne vurgu yapılarak klasik edebiyat tarihinde gözden uzak kalmış varlığına dikkat çekilmiştir. Böylelikle bu hezârfen şairin hem 19. yüzyıldaki edebî zevke kattıkları, hem de o yüzyılın diğer şairleri yanındaki yeri biraz daha belirginleşmiştir. 


\section{9. yüzyıl}

III. Mustafa (1755-1774), I. Abdülhamid (1774-1789), III. Selim (1789-1807) ve II. Mahmud (1808-1839) gibi dört padişah devrini gören Şânîzâde Mehmed Atâullâh, siyaset, askeriye, bilim, eğitim, ekonomi ve edebiyat alanlarında oldukça hareketli bir dönemde dünyaya gelmiştir. Bu dönemle ilgili özetle şu bilgiler verilebilir: 18. yüzyıldan itibaren Osmanlı' da ilk adımları III. Selim ile atılan bir takım yenileşme hareketleri baş gösterdi. Bu adımlar arasında Nizam-ı Cedîd adıyla Avrupa örnekli bir ordu kurulması, Mühendishâne-i Bahrî-i Hümâyûn (1773), Mühendishâne-i Berrî-i Hümâyûn (1795) gibi yüksek teknik okulların açılması gibi faaliyetler vard1. II. Mahmud ile birlikte sırasıyla Yeniçeri Ocağ kaldırdı (1826), orta öğrenim okulları, harp okulu, tıp okulu vb. eğitim kurumları yine Avrupa modeline göre düzenlendi. Batıya öğrenciler gönderilerek bilim, teknik, eğitim yeniliklerinin Osmanlı'ya gelmesi kolaylaştırıldı (Erdoğan, 2016: 3-5). Bu yeniliklerin Osmanlı'nın bilim ve teknolojide istenen yeniliği yakalamasına faydalı olacağı düşünülüyordu (Yılmazer, 2010: 334). Tıp alanında da ilerlemeler kaydedildi. İlk Tıp Mektebi bu dönemde açıldı (1827). 1832' de Tercüme Odası'nın açılmasıyla batılı diller özellikle de Fransızca eğitim kaynaklarının önü açılmış ve pek çok siyaset adamı ve edibin yetişmesinde rol oynamıştır. 1839 ' da Tanzimat Fermanı'nın ilanıyla devletin yönetim anlayışı değişerek bu farklılaşma kurumlara yansıtılmıştır. 1876' da Meşrutiyet'in ilanı ve Kânûn-1 Esâsî'nin kabulüyle siyasetin merkezi değişmiştir (Mermer vd., 2015: 560-561). Toplumun kültür seviyesini arttırmak ve batı seviyesinde telif, tercüme eserler ortaya koymak amacıyla Encümen-i Daniş kurulmuş (1851), diğer taraftan klasik edebiyat zevkinin batılılaşma karşısında yok olmasına mani olmak gayretiyle 1861'de Encümen-i Şu'arâ adıyla yeni bir oluşum meydana gelmiştir (İsen vd., 2003: 153, 155).

Kısaca, bu yüzyıl, Osmanlı'nın ordu, yönetim, eğitim, tıp ve edebiyatta önceki asırlarda olduğu gibi kalmadığı; eski ile yeniyi, klasik ile moderni, doğu ile batıyı birleştirme çabasıyla değiştiği bir dönem olup önde gelen şairleri arasında Enderunlu Vasıf (ö. 1824), Keçecizâde İzzet Molla (ö. 1829), Dâniş (ö. 1830), Aynî (ö. 
1837), Pertev Paşa (ö. 1837), Leylâ Hanım (ö. 1848), Şeyhülislâm Arif Hikmet (ö. 1859), Şeref Hanım (ö. 1861), Leskofçalı Gâlib (ö. 1867), Osman Nevres (ö. 1876), Yenişehirli Avnî (ö. 1883) ve Kâzım Paşa (ö. 1889) sayılabilir.

\section{Hayatı}

Şânîzâde, 1771 yılında İstanbul Ortaköy'de doğdu. Bununla beraber müderris tayin edildiğinde yaşının küçük olması (15 yaşında), onun kaynaklarda belirtilen tarihten 3-5 yıl daha erken (1766-67) doğmuş olması ihtimalini yükseltmektedir (Yılmazer, 2010: 34). Şânîzâde'nin babası özellikle fıkıh ilmindeki üstünlüğüyle tanınmış olan âlim, müderris ve aynı zamanda Medine kadılığında bulunan Hacı Mehmed Sadık Efendi'dir (ö. 1791). Dedesi ise bir müddet Mahmud Paşa Şer'iyye Mahkemesi kâtibi olan Hacı Mustafa Efendi'dir (Arslan, 2009: 2). Manzumelerinde isminin kısaltılmış hali olan "Atâ" mahlasını kullanan şairin ailesi, dedesinin babası Ahmed Efendi'nin "Şânî” (Tarakçı) lakabıyla tanınmasından ötürü Şânîzâde diye anılmaktadır. Atâ, ilk tahsilinden sonra ilmiye mesleğini seçerek Halıcıŏglu Mühendishanesi ve Süleymaniye Tıp Medresesi'nde tahsilini sürdürmüştür. Müsbet ilimlerin yanında dile de meraklı olan Şânîzâde, Arapça ve Farsça gibi Doğu dillerinin yanında İtalyanca, Fransızca, Rumca ve Latince de öğrenmiştir. Medrese tahsilinde ulûm-1 cüz'iyye, hesap, heyet, ilm-i hikmet, mantık, belâgat, kelâm, fıkıh, akâid, hadis ve tefsir derslerini almış; mühendishanede ise Fransızca, Arapça, geometri, aritmetik, coğrafya, cebir, trigonometri, diferansiyel ve integral hesap, astronomi ve istihkâm derslerini görerek doğu ve batı ilimlerini öğrenmiştir. Bu durumun Şânizâde'ye çok yönlülük kazandırdığı muhakkaktır (Erdoğan, 2016: 17). 1785 senesinde müderris olan şair, 1788 senesinde ordu kadısı olan babasıyla birlikte uzun süre ordularda bulundu. Şânîzâde müderris olduktan sonra sırasıyla, Örekezâde, Sâniye-i Fâtıma Sultân (1790), Dersiyye-i Hâne-i Ümmühânî, (1793), Sahhâf Karaca Ahmed (1796), Müftü Hüseyin Efendi (1806), Hoca Hayreddin ve Hâkâniyye-i Vefâ (1808) gibi medreselerde ders verdi. 1816' da Eyüp kadısı olarak atandı ancak 1817 'de azledildi. 1821 yılında kendisine evkaf müfettişliği ve Mekke kadılığı payesi verildi. Sonra da ömür boyu müfettiş-i 
sadr-1 âlî olarak görevlendirildi. Ancak aynı yıl görevine son verildi (Arslan, 2009: 2). O yıllarda Ortaköy Yârânı da denen Beşiktaş Cemiyyet-i İlmiyye' sine dâhil oldu (İhsanoğlu, 2008: 471). 1826’ da Mekke payesi ve Menemen arpalığı ile emekli oldu. Vak'anüvîs Mütercim Âsım Efendi'nin 1819'da vefat etmesi üzerine II. Mahmud, Şânîzâde'yi vak'anüvisliğe getirdi. Padişahın isteğiyle II. Mahmud'un cülus tarihi olan 1808'den başlayarak tarih eserini yazmaya başladı ve 1821'e kadar yazdı. Kendisinin yazamad1ğ1 1821-1826 arasındaki olaylara ait notları ise halefi Sahhâflar Şeyhizâde Es'ad Efendi'ye yazdırdı. Şânîzâde'yi rakip olarak gören Mustafa Behcet Efendi ve başka kimselerin de çabalarıyla 1825 senesinde vak'anüvislikten azledildi. 1826 yılında emekli edilen Şânîzâde, İstanbul'da etibbâ reisi olup bir müddet Süleymâniye Tıp Medresesi'nde ders vekilliği de yaptı. Yeniçeri Ocağı'nın kaldırılması esnasında Bektâşîlik müntesipleri sürgüne gönderiliyordu. Şânîzâde, Beşiktaş Cemiyyet-i İlmiyye'sine üye olduğu ve aynı cemiyetin toplantılarına Bektaşî şeyhi Mahmut Baba da iştirak ettiğinden kendisinin Bektâşî olduğu iddia edilerek arpalığ1 Tire'ye (İzmir) sürgün edildi (Yılmazer, 2010: 334). Şânîzâde'nin sürgünde iken vaktini nasıl değerlendirdiği pek bilinmemekle birlikte, orada Mihalzâde Lütfullah Efendi'nin konağında misafir olduğu, İstanbul'dan, kitapları, çalışmaları ve arkadaşlarından ayrı kaldığı için üzgün olduğu sanılmaktadır (Erdoğan, 2016: 17). İki ay kadar sonra orada vefat etti. Kaynaklar, Şânîzâde gibi bir âlimin sürgün edilmesine razı olmayan II. Mahmud'un af fermanı gönderdiği, ancak fermanı getiren görevlinin şairin konağına girerek telaşla dilinin sürçtüğü ve “Şânîzâde'nin itlafına ferman getirdim" demesi üzerine Şânîzâde' nin fenalaştığı ve kısa bir süre sonra vefat ettiği söylenmektedir.

Tire'nin Kışla bölgesi civarında defnedilen Şânîzâde'nin kabri, mezarlığın 1916 yılında kaldırılmasıyla bir müddet kayboldu. Bir müddet sonra tesadüfen bulunan mezar taşı Tire Müzesi'ne nakledildi. Günümüzde Tire'de Şânîzâde adını taşıyan bir meydan ve cadde; aynı cadde üzerinde 1973 yılında yapılmış bir anıt ve hastane bahçesinde 1950 yılında yapılan anıtın üstüne yerleştirilmiş bir büstü mevcuttur (Çipiloğlu, 2005: 16). 
Matematik, hukuk, tarih, edebiyat ve coğrafya gibi ilim dallarında te'lif ve tercüme eserler veren Şânîzâde, tıp alanında da hem teorik hem de pratik çalışmalar yapmış, 19. yüzyıl Osmanlı İmparatorluğu'nun hezârfen denilebilecek ölçüde bir âlimidir. Aynı zamanda Avrupa'da gelişen modern tıbbın Osmanlı Devleti'nde benimsenip yerleşmesinde Şânîzâde önemli rol oynamıştır. Hatta onun çiçek aşısı konusunda hayvanlar üzerinde deneyler yaptığı ve hayli ilerlediği ve Sultan II. Mahmud'a İstanbul'da bir aşı kampanyası başlatılmasını tavsiye ettiği bilinir (Davison, 1995: 303). Kendisi, birçok değerli tıp kitabını İtalyanca ve Fransızcadan Türkçeye tercüme eden kişi olmasının yanında Osmanlı' da ilk basılı tıp kitabının müellifi olarak da kabul edilir. Bursalı Mehmed Tahir Efendi, onun yeni eğitimin ilk üstatlarından biri olarak görmüş ve tıbbî ve fennî terimlerin ilk kez Şanîzâde tarafından kullanıldığını ifade etmiştir. Cevdet Paşa da, tarihinde Osmanlı diline ait tıp terimlerini ilk ortaya koyanın ve yerleştirenin o olduğunu söylemektedir. Şânîzâde'nin tıp alanında beş kitaptan oluşan külliyatı olup bu eserler Hamse-i Şânîzâde veya Kânûn-ı Şânîzâde adı ile tanınmıştır. Şânîzâde'nin kitapları Cem'iyyet-i Tibbiyye-i Osmâniyye'nin 1873'te hazırladığ1 Lugat-ı Tıbbiyye'ye temel teşkil etmiş, böylece Şânîzâde aynı zamanda Türkçeleşme akımına da katkıda bulunmuştur. Şânîzâde'nin astronomi ve astroloji ilimleriyle de meşgul olduğu bilinmekteyse de bu konularda bir eser kaleme almamıştır. Ayrıca onun yaşadığı dönem için oldukça yeni bir ilim dalı olan arkeolojinin, tarihe kaynaklık etmesi hususunu meşhur tarihinin mukaddimesinde zikretmiş olmasının, Şânîzâde'nin bazı kitaplarını yazarken Avrupa'daki eserlerden faydalandığı görüşünü uyandırdığ1 kaynaklarda zikredilir (Eldem, 2013: 18). Şânîzâde, tarihinde de yer yer her iki alanda (tarih ve arkeoloji) görüşlerini ortaya koymuş ve Divan'ında bu ilim dallarında ait terimleri kullanmıştır. Tıp, matematik, astronomi gibi fen bilimlerinin yanında tarih ve edebiyat gibi sosyal ve beşerî alanlarında da eser veren şairin ilmî mahareti sadece bu alanlarda kalmamış Şânîzâde musiki, resim ve hat gibi sanat dallarında da kabiliyetini ortaya koymuştur. Sülüs ve nesihi İsmail Zühdî Efendi (ö. 1806); talik 
hattını ise Yesarî Efendi (ö. 1798) gibi zamanındaki ünlü üstatlardan öğrenmiştir. Bunların yanı sıra Şânîzâde'nin saat yaptığ1 ve usta bir avcı olduğu (Yılmazer, 2010: 13), çiçek yetiştirmeyi, bitkileri incelemeyi sevdiği ve içindeki kitaplarla vakit geçirmekle huzur bulduğu güzel bir kütüphanesinin bulunduğu kaynaklarda kaydedilir (Erdoğan, 2016: 13). Hem kendisinin hem de ondan bahseden eserlerin bahsettiğine göre, Şânîzâde'nin bilgisi ve kabiliyeti saraydaki bazı çevreler tarafından kıskanılmış ve onun ilmine layık mevkilerde bulunmasına mani olunmuştur (İnal, 1935: 106).

Şânîzâde'nin Tire Müzesi'nde 1453 numara ile kayıtlı olan mezar taşında şairin ilmiye sınıfından olduğunu gösteren bir kavuk mevcuttur (Ülker, 1994: 197). Şânîzâde'nin mezar taşında kimin tarafından kaleme alındığı bilinmeyen şu mısralar yazılıdır:

"Müyesser oldu bana şehâdet

İlâhî sen nasîb eyle sa'âdet

Bulam tâ ki Resûl'ünden şefâ'at

Şâni-zâde Mehmed 'Atâ'ullâh Efendi bâ-emr-i 'âlî Tire'ye me'mûr iken merhûm oldu. Ruhu içün rızâen lillâhi Te'âlâ Fâtiha el-Gurre-i Muharrem sene 1242 (1826)."

Şânîzâde'nin ilimle meşgul bir aileden gelmesi ve Osmanlı'nın son asır kimliğine uygun olarak Doğu ve Batı ilimleriyle mücehhez olması onu pek çok alanda velut hezarfen bir kişilik yaparak pek çok eser vücuda getirmesine vesile olmuştur. Şânîzâde'nin bu eserlerini bilim tarihçisi Esin Kahya kendi tasnifiyle iki gruba ayırmıştır: Tıpla ilgili olanlar ve bunun dışında kalanlar (Erdoğan, 2016: 13). Muhtelif araştırmacılarca eserleri detaylıca incelenmiş olan Şânîzâde'nin çalışmalarından bazıları şunlardır: Şânî-zâde Târîhi, Hamse-i Şâni-zâde (Mir'âtü'l Ebdân Fî Teşrîh-i $A^{\prime} z \hat{a}^{\prime} i^{\prime} l-i$ İnsân, Usûlü't-Tabî'a, Mi'yârü'l-Etibbâ, Kânûnu'l-Cerrâhîn, Mîzânü'l-Edviye'den oluşan beş tıp kitab1), Ruhye (Rûhiyye) Risalesi, Cebir ve Mukâbele, Istılâhât-ı Etibbâ, Mürekkebât-ı Eczâ-yı Tıbbiyye, Risâlesi, Tanzîm-i Piyâdegân ve Süvâriyân, Usûl-i Hendese, Tenbîhât-ı Hükümrân Bâ-Ser-askerân ve Divan (Erdoğan, 2016: 53-54). 


\section{Şair olarak Şânîzâde Mehmed Atâullâh}

Yaşadığı devirde sahip olduğu ilmî müktesebat ve çeşitli lisanlara hâkimiyeti ile tanınmış olan Şânîzâde Mehmed Atâullâh Efendi, ne yazık ki şiir alanındaki kabiliyeti ile öne çıkmayı başaramamış bir şairdir. Onun bazı ilim dallarında özellikle tıp ve tarihte geniş şöhret bulmuş olması, şair yönünün fark edilmesine engel olmuş olsa gerektir. Çünkü onun şiirde de maharet sahibi olduğu pek çok kaynakta dile getirilmiştir. Sözgelimi, Osmanlı tarihçileri hakkındaki Âyine-i Zürefâ' da Şânîzâde'nin âlim ve fâzıl (Süreyya, 1996: 360) olmasının yanında "ilm-i nücûmda şöhreti âşikâr, şiir ve inşâda sâhib-i iştihâr" (Cemaleddin, 2003: 69) olduğu söylenmektedir. Sadettin Nüzhet Ergun, onun çok güçlü bir sanatkâr olmamasına rağmen şiirlerinin edebî kıymetten büsbütün uzak olmadığını ifade eder (Ergun, 1935: 530). İbnül Emin Mahmut Kemal ise ilimde ileri gitmiş bir sanatkâr olduğundan Şânîzâde'den kudretli şairler ölçüsünde şiirler beklemenin ona haksızlık olacağını belirtir (İbnül Emin Mahmut Kemal, 1969: 110 ve 115).

Klasik Türk edebiyatında her şairin ortak bir dili, ortak mazmunları ve ortak söyleyişlerinin olması kadar onların birbirinden ayırt edici vasıflara sahip olmaları da tabiidir. Yaşadıkları yüzyıl, aldıkları eğitim, yetiştikleri çevre, sosyal ve kültürel bağları, etkilendikleri şairler vb. şiirlerindeki ayırt edici özellikleri belirleyen faktörlerdir. Yukarıda kaynaklarda söylenenler dikkate alındığında Şânîzâde hakkındaki kanaat ve onun diğer şairlere benzeyen vasıfları az çok ortaya çıkmaktadır. Onlara ilaveten onun şairliği hususunda söylenecekler elbette Divan'ı üzerinde yapılacak incelemelerle somutlaşacak ve netleşecektir. Bu özelliği taşıyan kaynaklardan biri Şânîzâde'nin Divan'ı üzerinde olan iki çalışmadan biri olan Meserret Diriöz'ün makalesidir. Diriöz burada, Osmanlı'nın hemen her alanda değişiklik ve yeniliğe uğradığı bir dönemde Şânîzâde'nin klasik şiir çizgisini devam ettirmeyi başardığını, dili, aruzu, mazmunları, sanatları ve konularıyla divan şiirini tam olarak temsil ettiğini söyler ve Şânîzâde' yi üç dilde şiir yazan iyi bir şair olarak niteler (Diriöz, 1989: 25). Aynı özelliği taşıyan ikinci kaynak ise Divan'ını tenkitli metnini hazırlayarak gün yüzüne çıkaran bunlara ilaveten Divan üzerinde şekil ve muhteva inceleme- 
si yapan makalemizin de dayandığ1 Adviye Rabia Çipiloğlu'nun yüksek lisans tezidir. Çipiloğlu, çalışmasının Ergun ve Diriöz'ün Şânîzâde hakkındaki yorumlarını doğruladığını söyler. Ayrıca Şânîzâde'nin klasik çizgiden ayrılmamakla birlikte divan şiirinde yenilikler arayan ve bunu dili ve mazmunlarıyla gösteren bir şair olduğunu ifade eder (Çipiloğlu, 2005: 73-74).

\section{Divan'1}

Şiirlerinde mahlas olarak Atâ'yı kullandığından Şânîzâde'nin Divan'ı Atâ Divanı olarak bilinir. Vefatından sonra tertip edilen Divan'ının üçü İstanbul'da (İstanbul Üniversitesi Ktp. Nadir Eserler, T, nr. 1352; T, nr. 9636; Yapı ve Kredi Bankası Sermet Çifter Araştırma Ktp. nr. Y 727), biri Viyana Millî Ktp. nr. 750) olmak üzere şimdilik bilinen dört nüshası mevcuttur (Erdoğan, 2016: 43). Bunlardan başka İstanbul Üniversitesi Ktp.'de Nadir Eserler, T, nr. 9749'da Şânîzâde'nin kendi hattıyla yazdığı ve Divan'da yer almayan bazı şiirlerinin de yer aldığı bir defter bulunmaktadır (Yılmazer, 2010: 336). Atâ Divanı'nın İstanbul Üniversitesi Ktp. Nadir Eserler Bölümü'nde kayıtlı olan T 1352 no'lu nüshasında 1 kaside, 12 tarih, 1 Farsça takriz, 1 tahmis, 75 gazel, 10 kıt'a, 12 rubai ve 25 beyit yer almaktadır. Divan'daki toplam beyit sayısı ise $663^{\prime}$ tür.

Divan'daki ${ }^{1}$ manzumelerin nazım şekilleri ve muhtevaları şu şekildedir:

Kaside: Divan, III. Selim'e (ö. 1808) yazılmış şitâiyye türünde Türkçe bir kaside ile başlar. 66 beyitlik bu kasidenin nesîb bölümünde sıcakların yerini soğuklara ve yağmurlara bırakması ile sonbaharla birlikte yeryüzünde meydana gelen değişiklikler çeşitli sanatlarla tasvir edilmiştir (b. 1-22) ${ }^{2}$. Medhiye bölümünde padişah III. Selim'in âleme hükmeden tedbirli ve adaletli bir padişah olarak ülkenin iklimini değiştirip havasını güzelleştirdiği söylenir (b. 23-50). Fahriye bölümünde şair III. Selim'in övgüsü için şiirini konuşturduğunu söyleyerek hem sultanı hem de kendisini yüceltir. Beyitlerden Şânîzâde' nin kendi şiirine güvendiğini ama kendi-

1 Adviye Rabia Çipiloğlu'nun hazırladığı tenkitli metin kastedilmektedir.

2 Rakamlar, kasidenin beyit aralıklarını göstermektedir. 
ni III. Selim'den daha üstün görmediği anlaşılmaktadır (b. 51-58). Kasidenin dua bölümünde padişahın ömrü ve devletinin devamı, şevket ve şöhretinin tanınması, düşmanlarının mağlup ve mahcup olması için dua edilir (b. 59-66).

Tarihler: Kasideleri takiben tarihler yer alır. Şânîzâde aynı zamanda tarihçi olmasının da etkisiyle 1796 ile 1842 yılları arasında geçen ve kendince önemli gördügü bazı olaylara tarih düşürmüştür.

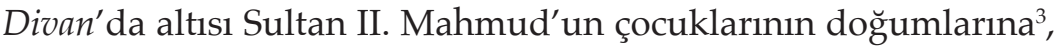
biri Borlu'da İzzet Ali Paşa Camii'nin yapılışına (1796), biri Şeyhülislam Atâ Efendi'nin ev yaptırmasına (1817), biri Beylerbeyi Camii'nin minaresinin tamirine (1821), biri tersane yenilenmesine (1821), biri Silahdar Ali Paşa'nın sadrazam oluşuna (1823), biri Galip Paşa'nın sadrazam oluşuna (1824) olmak üzere on iki tarih manzumesi mevcuttur. Tarihler Türkçe olup 7. tarihin ilk beyti Farsça; 9 ve 12. tarihlerin ilk beyitleri Arapça yazılmıştır.

Takriz: Farsça'dır. Çağdaşı divan şairi İsmail Ferruh Efendi'in (ö. 1840) (Arslan, 2019: 1) Mesnevi Şerhi için için yazılmış 7 beyitlik bir takrizdir.

Tahmis: Tokatlı divan şairi Kânî’nin (ö. 1792) bir gazeline yazılmış 5 bentlik Türkçe bir tahmistir.

Gazeller: Atâ Divan'ında 75 gazel bulunmaktadır. İlk iki gazel tevhid türündedir. Gazellerin 53'ü 5, 16's1 7, 1'i de 8 beyitten oluşmaktadır. Gazellerin muhtevası aşk, meyhane, hastalıklar, musiki, tasavvuf vb. konulardır. Divan'daki 10. gazel mülemma gazel olup 6 beyitliktir. 1 ve 4. beyitler Arapça, 2 ve 5. beyitler Farsça, 3 ve 6. beyitler ise Türkçe yazılmıştır. ${ }^{4} 17$. gazel tamamen Farsça' dır. Ayrıca ilk ve ikinci beyitleri Arapça ve Farsça olan gazeller mevcuttur.

Mukatta'ât: $\mathrm{Bu}$ bölümde 12 kıt'a ve 12 rubai bulunmaktadır. Kıt'alar Türkçe olup biri, ilki Farsça ikincisi Arapça olan misralar ile başlar. Bir diğeri de Arapça bir mısra ile başlar. Ayrıca bir

3 Detaylar için bkz. Adviye Rabia Çipiloğlu, a.g.e., s. 30.

4 Bkz. Adviye Rabia Çipiloğlu, a.g.e., s. 115-116. 
kıt'ada ayetten iktibas yapılmıştır. Çoğu tasavvufî mahiyette olup sadece birkaçı aşk ve güzellik üzerinedir. Rubailer Türkçe olup bazıları ayet iktibasları barındırmaktadır. Divan nüshalarından birinde rubailerin Ömer Hayyam (ö. 1131) tavrında yazıldığına dair ibare vardır. Rubailerin konuları, Allah'ın zatına övgü, tasavvuf, aşk ve ayrılık şeklinde özetlenebilir.

Beyitler: Divan'da tamamı Türkçe ve çoğu tasavvufî mahiyette olan 25 beyit bulunmaktadır.

Atâ Divan' 1 'ndaki manzumelerde 54 şiirle en çok remel bahrinin, 1 şiirle en az hezec' in ahreb kalıbının kullanıldığ1 görülür. Şânîzâde, aralarında tıp, astronomi, tarih, musiki, tasavouf gibi alanların da oldu$\breve{g} u$ kendisinin mahir olduğu hemen her ilmi Divan'ına taşımıştır. Ayrıca şiirlerinde peygamber kıssaları, mitolojik olaylar ve şahsiyetler ve Hz. Peygamberin mucizelerine de gönderme yapılmıştır. Bunlardan başka zamaneden, felekten şikâyet, aşk, ayrılık, hastalık, vb. konular da yer alır. Ayrıca klasik Türk edebiyatının pek çok sanatı ve bilinen dört üslubu (klasik, sebk-i hindî, mahallî ve hikemî tarz) bir arada kullanmıştır.

Şânîzâde, Divan'ında Türkçe'nin yanı sıra Arapça şiirlere de yer vermiştir. Ayrıca, ayet ve hadislerden iktibas yapmış, Arapça atasözü ve deyimleri de kullanmıştır. Divan'da Farsça manzumeler ve Farsça kelime kafiyeleriyle yazılmış şiirler de mevcuttur. Kasidelerinde ve bazı şiirlerinde yer yer dili ağırlaşsa da Atâ, gazellerinde nispeten daha sade bir dili tercih etmiştir. Bununla beraber Şânîzâde'nin tarihleri, uzun ve zaman zaman soyut kelimelerle kurulu tamlamalarla yazılmış beyitlerden oluşmuş olup bunlar onun dili en ağır olan manzumeleridir denebilir:

Zafer-fer hazret-i sadr-1 sa'îd Gâlib Mehemmed kim

Merâmı dâ'imâ hakk-1 'ibâda hayrı câlibdir (T. 11/1)

Kit'alar ve rubailerinde sade bir üslup kullanmış olmakla birlikte Arapça, Farsça ve Türkçe kelimeleri bir arada kullanarak yazılanlarında dil yoğunlaşmıştır:

Müttehid ber-vefk-i hikmet asl-1 eşyâ bî-nizâ'

Yettehid fî zâtihim hattâ'z-zilâli ve'ş-şu'â' 
Sâye cism-i muzlimin haylûleti âsârıdır

Cism-i şeffâf zılli kat'en olmamıştır istimâ‘ (Kıt'a 8)

(Eşyanın aslı, tartışmasız bir şekilde hikmete münasip olarak birlik etmekte. Gölgelerden 1şıklara kadar her şey asıllarında birleşmekte. Gölge, karanlık (şeffaf olmayan) cismin (ışı̆̆a) engel olmasının eseridir. Şeffaf cismin gölgesini(n olduğu) ise asla duyulmamıştır.)

Şânizâde zaman zaman sade söyleyişin olduğu kadar yer yer sebk-i Hindi'nin, hikemî tarzın ve klasik üslubun örneklerini $D i$ van'inda vermiştir.

Aşağıdaki beyti sade söyleyişine örnek olarak göstermek mümkündür:

Bilmedim evvel kemâhî böyle ben dil-cû sizi

Sayd idip deryâ-dil olduk şimdi ey meh-rû bizi (G.75/1)

(Sizin böyle gönül aldığınızı ben önceden hakkıyla anlayamamış idim. Ey ay yüzlü! Siz bizi avladınız da biz öyle geniş gönüllü olduk.)

Sebk-i hindîye örnek olarak ise şu beyit verilebilir:

Harf-i vefâ şenîde-i la'l-i lebi değil

İmdâd-hâh-1 keyfiyet-i bâdeyiz yine ( G. 69/2)

(Onun dudağının şarabından vefanın bir harfi (bile) duyulmuş değildir. Biz yine badenin keyfiyetinden medet ummaktayız.)

Klasik üslup örneği:

İdip bu rûzgâr endîşe-i felekden dûr

'Arûs-1 èâlemin meşşâta-i mihr oldu hayrânı (G. 74/2)

(Zaman, feleğin endişesinden uzak eyledi de güneş süsleyicisi âlem gelininin hayranı oldu.)

Hakîmâne üslup örneği:

Riyâdan hırka-pûş oldunsa pâk it cebhe-i cismi

Mülevves-dâmen-i dehr olma kirpâs-1 riyâlıkdan (G. 62/4)

(Riyadan hırka giymiş isen, beden sathını temizle! Riyalık bezinden dünyayla eteğin kirlenmesin!) 
Bunlara ilaveten şair, ara ara Nedimâne üsluba da yer vermiştir.

Seyr it âyine-beden o sanem-i Efrenci

Ham-ı gîsûları benzer Flemenk sünbülüne (G. 67/2)

(Parlak vücutlu o Avrupalı güzele bir bak! Saçlarının kıvrımları Flemenk sümbülüne benziyor!)

Atâ'nın gazellerinde sadeliği sağlayan unsurlardan biri olarak günlük konuşma dilini, atasözü ve deyimleri de görmek mümkündür: Ağzına almak, asılmak, baştan çıkarmak, çokbilmiş, döner dede, gece basılmak, felekten bir gün uğurlamak, göz hapsine almak, kapılmak, ipliği pazara çıkmak, kesinkes, kuşça can, püsküllü bela, takılmak, teline dokunmak, dilleşmek, yıkılıp gitmek gibi örnekler Atâ Divanı'nı hem süsleyen hem de zenginleştiren kullanımlardır (Diriöz, 1989: 22). Şânîzâde'nin birçok ilimle ve sanatla mücehhez dünyasında şiirlerinin de göz ardı edilemeyecek ifade ve mana cazibesine sahip olduğu söylenebilir. Tasavvufî remizler ve ifadeler içeren beyitlerinin nicelik ve niteliği; ayrıca tahmis için Mevlevî bir şairi (Kânî) ve takriz için İsmail Ferruh Efendi'nin Mesnevi Şerhi'ni tercih etmiş olması, onun sadece ifade zevki denemeyecek ölçüde tasavvufî yöneliminin olduğunu hatta kesinliği ispat edilmemiş de Mevlevî-meşrep olabileceğini düşündürmektedir.

\section{Bazı Kavram ve Konularla Atâ Divanı'nın Muhtevası}

\section{Allah:}

Zâhir ve Bâtın'dır.

Zâhir ü Bâtın dilâ ancak o Zât-i Pâk'dir

Merdüm-i âgâh isen senden garaz idrâkdir (G. 24/1)

(Ey gönül, zâhir ve bâtın olan yalnızca O Temiz Zât'tır. Şayet sen manen uyanık bir insansan, senden beklenen O'nu idrâk etmektir.)

İsimleri sayısızdır:

Zât:

Cümle esmâ müntehîdir çünki Zât-1 Vâhid'e Lafz u ma'nî nokta-i Kur'ân içinde gizlidir (G. 19/2) 
(O Yegâne Zât olan Allah için bütün isimler sinırlı olduğundan lafız da mana da Kur'an'ın bir tek noktası içinde gizlidir.)

Yezdân:

Dehr-i fânîde dilâ mahlûktan yok mültemes

Her nefes ben zâra lutf-i hazret-i Yezdân bes (G. 38/1)

(Fani dünyada yaratılmışlardan kayırılan yoktur. Benim gibi ağlayıp inleyen birine her nefeste Hz. Allah yeter.)

Hiçbir yere sığmaz, mü'minin kalbinde gizlenir:

Sığmayan tenzîh ile kevn ü mekân $\mathrm{u}$ 'arşa hem

Mü'minin kalbindedir her an içinde gizlidir (G. 19/3)

(Övgüyle arşa, kevn ve mekâna sığmayan Allah, her daim içinde gizlendiği mü'min kulunun kalbindedir. ${ }^{5}$ )

\section{Kur'ân:}

Kur'ân farklı isimlerle anılır:

Hak zâhir ü bâtında hem kılmış imâm-1 müslimîn

İsbât-1 da'vî eylerim ister isen Furkân'dan (T. 4/3)

(Allah onu hem zâhir hem de bâtında Müslümanların imamı tayin etmiştir. Eğer istersen bu davamı Furkân'dan ispatlarım.)

Kur'ân'dan kelime veya ayetlerle iktibas yapılmıştır:

Lem yelid remzini lem yûled yüzünden keşf ider

Kim ki ihlâs ile sırr-1 Hakk'a olsa âşinâ ( G. 1/3)

(Her kim Hakk'ın sırrına ihlas ile yakın olsa, "lem yelid" (doğmamıştır) sırrını "lem yûled" ${ }^{6 "}$ doğurulmamıştır ) vesilesiyle keşf eder.)

5 Tasavvufî kaynaklarda çokça dile getirilen “Kalb, Allah'ın arşıdır, yerlere ve göklere sığmayan Allah mü'min kulunun kalbine sığmıştır." ifadesinin bir hadis-i kutsi olduğu rivayet edilmektedir. Bkz. Süleyman Uludağ, (2001), “Kalb", 07.01.2020 tarihinde https:/ / islamansiklopedisi.org.tr/ kalb sitesinden alınd1.

6 "Ondan çocuk olmamıştır (Kimsenin babası değildir). Kendisi de doğmamıştır (kimsenin çocuğu değildir)." el-İhlâs: 3. 
Duzâh-1 cehli koyup gel cennet-i 'irfâna gir

lsa lâ havfün 'aleyhim olmaya hüzn ü belâ (Kıt'a 3)

(Cehalet Cehennem' ini birak da irfan Cennet'ine gir. "Onlara korku yoktur"7 âyeti olunca, hüzün ve bela olmaz.)

Bir kûze-gerin çarhına saldım enzâr Çok kâseleri devr ile eyler hem-vâr Vird itmede hâliyle ol ihrâk her-bâr

"Halaka'l-insâne min-salsâlin ke'l-fehhâr" (Rubai 8)

(Bir çömlekçinin çıkrığına göz attım, birçok kâseyi döndürerek muntazam hâle getiriyor. $\mathrm{O}$ ateş, hâl ile tekrar tekrar zikrediyor: "Allah insanı, pişmiş çamura benzeyen bir balçıtan yarattı. ${ }^{8 \prime}$ )

\section{Peygamberler:}

Peygamberler kıssalarına telmihle anılır:

Hz. İbrahim (as) ve ateş:

Nâr içre gülistâna sa'y eyle çü İbrâhîm

Dehrin ki bahârında bir lahza devâm olmaz (G. 33/5)

(Hz. İbrahim gibi ateş içindeki bahçeye (varmak için) çalış, gayret et. Çünkü dünyanın ilkbaharı hep devam edecek değildir.)

Hz. Dâvûd (as) ve güzel sesi:

Hevâ vü nakş değildir terâne-i 'uşşâk

Odur bu kâr-1 hakîkatde nağme-i Dâvûd (G. 16/5)

(Âşıkların teranesi arzu ve hile değildir. Bu hakikat işinde o ancak Davud'un nağmesidir.)

Hz. Muhammed (sav) ve O'ndan yardım istenmesi:

Eğer olmazsa senden lutf u şefkat yâ Resûlallâh

Yamandır hâl-i pür-'isyân-ı ümmet yâ Resûlallâh (G. 65/1)

(Yâ Resûlallâh, eğer senden lütuf ve merhamet olmaz ise, ümmetin isyanla dolu hali pek fenadır.)

7 "Şüphesiz Rabbimiz Allah'tır" deyip sonra da dosdoğru olanlara hiçbir korku yoktur, onlar üzülmeyecekler de." el-Ahkâf: 13.

8 "Allah insanı, pişmiş çamur gibi bir balçıktan yarattı." er-Rahman:14. 
Şakku'l-kamer mucizesi:

Rû-be-rû şakku'l-kamer esrârını îmâ eder

Sîne-i mihrâb-1 ebrû ol vecihden çâkdir (G. 24/2)

(Kaş mihrabının göğsü, ayın yarılması (mucizesinin) sırlarını açıkça îmâ ettiği için yarıktır.)

\section{Tasavvuf:}

Kâinatın temelindeki aşk vardır.

Çün hayât-1 'aşk ile geldi vücûde kâinât

'Âlem-i tahkîkde ref' oldu külliyen memât (B. 6)

(Kâinat, aşkın canlılığı ile var olduğu için gerçek âlemde ölüm, topyekûn yok oldu.)

Hakiki aşka erenlerin emeli vuslat değildir:

Gönül mellâh-1 bahr-i '1şk olaldan keştî-i tende

Dem â dem mâ'il-i girdâbdır meyl-i kenâr itmez

Temennâ-yı cefâ-yı yâr idendir seyyid-i 'uşşâk

Celîs-ender harîm-i ‘'ş̧k olan vasl ihtiyâr itmez (Kit'a 6)

(Gönül, beden gemisinde aşk denizinin dalgıcı olalı beri daima girdaba meyledip durur da kıyıya çıkmayı istemez. Âşıkların efendisi, sevgilinin cefasına temenna eden kişidir. Aşk hareminde oturan kavuşmayı istemez.)

Sûfî:

İtdi mir'ât-1 dilin pür-jeng 'aks-i mâsivâ

Kalbin ey sûfî senin bir sûret-i puthânedir (G. 18/ 3)

(Masivanın aksi dil aynanı tozlandırdı. Ey sufi, senin kalbin artık puthane gibidir.)

\section{Tevhid:}

Tevhidden gayrısı insana dert getirir:

Merhem-i zahm-1 dil ancak kıssa-i tevhîddir

Bil 'Atâ tasdî̃ dir hep sergüzeşt-i mâsivâ (G. 2/ /7)

(Gönül yarasına merhem (olacak şey) tevhid kıssasından başkası değildir. Ey Atâ! Geri kalan her şey baş ağrısı verir.) 
Vildan S. Coşkun

\section{Gönül:}

Gönül Allah'ın evidir:

Bu harâbât içre kim hâk-ile yeksândır gönül

Lîk ma'mûre-i 'irfâna sultândır gönül

'Aks ider mir'ât-veş levhinde eşkâl-i suver

Kâ' inât içre mu'allâ 'arş-1 Rahmân' dır gönül (Kıt'a 2)

(Gönül bu meyhanede (dünyada) yerle bir olmuştur. Ancak o irfan memleketine sultan olmuştur. Görüntülerin suretleri ayna gibi sathında yansır. Gönül, kâinat içinde yüce Rahman'ın arşıdır.)

\section{Dert ve Derman:}

Ârifler için dert ve derman aynıdır:

Aslı birdir didiler zevk u cefânın 'ârifân

Bildim anı derd dahi dermân içinde gizlidir (G. 19/7)

(Ârifler, zevk ile eziyetin aslının aynı şey olduğunu söylediler. Derdin derman içinde olduğunu anladım.)

\section{Fakr:}

Fakirlik övünç kaynağıdır:

Mahrem olmuş fakr u fahrin remzine el-Hak 'Atâ

Kenz-i lâ yefnâyı ${ }^{9}$ bulmuş kân içinde gizlidir (G. 19/8)

(Atâ'nın "el-fakru fahrî”"10 işaretine mahrem (yakın) olduğu doğ-

9 Tükenmez hazine.

10 “Terim anlamı ise kişinin mevhum olan varlığından kurtulması ve fenafillaha mazhar olmasıdır. Fakr, hiçbir şeye malik olmadığını kabullenmektir. Fakir ise, bu dünyanın peşinde boş yere koşmaktan yüz çevirerek, hakikati, yani kendi varoluşunun sırrını soruşturandır. Bir başka deyişle fakir, her şeyden vazgeçerek, Allah Teâlâ'nın rızası ve inayetini araştıran sûfidir. Bu sufilerin varlığı Hz. Muhammed dönemine kadar inmektedir. Ashab-1 suffa bu anlamda ilk grup olarak değerlendirilmektedir. Hadis olup olmadığı tartışılan fakat mutasavvıflarca çok tutulan "El-fakru fahrî” fakirliğim övüncümdür sözüne istinaden fakr, tasavvufta ulaşılması hedeflenen bir mertebe konumundadır. Mutasavvıflar fakrı maddî ve manevî fakirlik olarak ikiye ayırmıştır. Bunlardan bir kısmı fakrı makamların en üstünü olarak kabul etmişlerdir. Ancak, mal mülk sahibi olmak mutasavvıfların 
rudur. $\mathrm{O}$, bir maden içinde saklı olan hiç tükenmeyecek bir hazine bulmuştur.)

\section{èAyne'l-yakîn:}

Sevgili, èaynel yakîn ile âşığın dilinden zuhûr eder:

Şöyle müstağrak hayâl-i yâra dil 'ayne'l-yakîn ${ }^{11}$

Kim odur güftâr iden şimdi lisânımdan 'Atâ (G.1/6)

(Ey Atâ! Gönül, yârin hayaline o kadar 'aynel yakîn (gözle görecek kadar) dalmıştır ki, benim dilimden çıan sözler O olmuştur.)

\section{Dünya:}

Hüner sahipleri bu dünya sofrasından nasipdar olmaz:

Ey 'Atâ kat'-1 ümîd eyle ki bir lokma dahi

Yokdur ehl-i hünere sofra-i 'âlemde nasîb (G. 9/5)

(Ey Atâ! Hüner sahiplerine âlem sofrasında bir lokma bile kısmet yoktur, (Bundan) Ümidini kes!)

Dünya, kendisi gibi kabiliyetli kişilere düşmandır:

Ben de bu dehr-i denîde şâdmân olmam èAtâ

Hasmdır erbâb-1 isti'dâda çün bu âsiyâb (G. 7/5)

(Ey Atâ! Bu alçak dünyada ben mutlu ol(a)mam. Çünkü bu değirmen istidat sahiplerine düşmandır.)

\section{Sevgili:}

Sevgilinin ikircikli tavırlarına bir âşık olarak sabretmek zordur:

işaret ettiği fakra engel değildir. Zira onların kastettiği fakr dünyevî değil, manevîdir." Aktaran Süleyman Solmaz, "Tasavvufta Ulaşılması Gereken Bir Mertebe: Elfakru Fahri ve Eski Edebiyatımıza Yansımaları (A Spiritual State to Reach in Sufi Tradition: Al-Faqr Fakhri", Uluslararası Hacı Bayrâm-ı Velî Sempozyumu Bildiriler Kitabı: 25-26 Mayıs 2016, 2016, cilt: II, s. 115-116.

11 Göz ile görüyormuş gibi bilmek. Filozoflar nefsin mertebelerinden biri saydıkları ayne'l-yakīni, "nefsin akledilebilirleri (ma'kûlât) müşahede ederek oldukları gibi kavraması" şeklinde tarif etmişlerdir. Bkz. Yusuf Şevki Yavuz, (1991), “Ayne'1 Yakîn”, 01.01.2020 tarihinde https:/ / islamansiklopedisi.org.tr/aynel-yakin sitesinden alındı. 
Hem 'itâb eyler a kâfir hem olursun şîvekâr

Ya nice olmaz 'Atâ sabr u tahammül 'âcizi (G. 75/5)

(Ey sevgili! Hem azarlıyor hem de naz yapıyorsun. (Bu) Atâ nasıl sabır ve tahammülden aciz kalmasın? (Ne bekliyorsun?)

Kendisinin bunca ihtimamına rağmen sevgili, oyun ve hilelerine devam ederek vefasızlık yapar:

Nerden ahz itdin gülüm bu nakş-1 reng ü âli sen

Olmamış mı hiç güzergâhın 'aceb semt-i vefâ (G. 3/3)

(Gülüm, sen bu hile ve oyun şeklini nerden öğrendin? Senin güzergâhın hiç vefa semti olmadı mı?)

Sevgilinin yan bakışları onu yaralasa da o vefada kararlıdır:

Ko tîğ-i gamzesi çâk eylesin şu sînemizi

Der-i vefâ bu mefâtihle olur meftûh (G. 14/6)

(Bırak kıyabakışının kılıcı göğsümüzü parçalasın. Vefa kapısı bu anahtarlarla açılır.)

Ayrılık, aşığı derinden yaralar ve sonsuz hüzne sevkeder:

Zehr-i hasret dâğ dil ${ }^{12}$ hecrünle gülşen sû-be-sû

Dem-be-dem beytü'l-hazen pây-1 hum-1 meyhânemiz (G. $36 / 3)$

(Ayrılığın sebebiyle yara hasret zehirine, gönül de yer yer gül bahçesine döndü. Meyhane küpünün dibi de her an hüzünler kulübesi oldu.)

Gönül ancak vuslat gecesinde güler:

Ruhsârına düşdü şeb-i vuslatta sirişkim

Handânî-i hâtırla o gonca güle düşdü $(737 / 3)$

(Kavuşma gecesinde gözyaşım sevgilinin yanağına düştü. O gonca, gönül sevinciyle (bir hayli eğlenip) hemen gülmeye başladı dönüştü.)

12 Tenkitli metinde dâğ-1 dil şeklinde okunmuştur. Bkz. Rabia Adviye Çipiloğlu, a.g.e.s. s. 133. 
Sevgilinin güzelliğini neye benzeteceğini şaşırmış gibidir:

Nükhet-i zülf ü 'izâr u hâlinin hayrânıyım

Gül müdür sümbül müdür fülfül müdür bilmem ne bu (G. $63 / 2)$

(Sevgilinin) Saçının, yanağını ve beninin kokusunun hayranıyım. $\mathrm{Bu}$ (veya bu koku) bilmiyorum gül mü, sümbül mü yoksa karabiber tanesi mi?)

O tam bir püsküllü beladır ${ }^{13}$ :

Serpûş-1 meziyyet ile işkeste-edâdır

Ol mûy-miyân ${ }^{14}$ başıma püsküllü belâdır (B.1)

(Meziyet başlığı ile nazı kırılmış bir haldedir. O kıl belli (olan sevgili) başıma püskülü bela olmuştur.)

Âşık:

Âşık, sevgilinin merhametine muhtaçtır:

Bu hâl-i zârıma şefkat nigâra gelmez mi

Su'âl-i haste-i hicrân-1 zâra' ${ }^{15}$ gelmez mi? (G. 72/1)

(Bu zavallı halim nedeniyle o güzel sevgiliye şefkat gelmez mi? Zavallı ayrılık hastasına hal hatır sormak için gelmez mi?)

Âşık için sevgilinin ikircikli hallerine tahammül zordur:

Hem 'itâb eyler a kâfir hem olursun şîvekâr

Ya nice olmaz 'Atâ sabr u tahammül 'âcizi (G. 75/5)

(Ey sevgili! Hem azarlıyor hem de naz yapıyorsun. (Bu) Atâ nasıl sabır ve tahammülden aciz kalmasın? (Ne bekliyorsun?)

Âşık için sevgilinin kıyabakışı bile vefa göstergesidir:

13 Mecaz yoluyla baş derdi, yorucu ve karışık iş yerine kullanılan tabirdir. Bkz. M. Zeki Pakalın, Tarih Deyimleri Ve Terimleri Sözlü̈̆̈̈̈, C. 2, Ankara MEB, 1971, s. 784.

14 Tenkitli metinde mûy-1 miyân olarak okunmuştur. Bkz. Adviye Rabia Çipiloğlu. a.g.e. s. 22.

15 Tenkitli metinde hicrân-zâra olarak okunmuştur. Bkz. Adviye Rabia Çipiloğlu, a.g.e., s. 156. 
Vildan S. Coşkun

Ko tîğ-i gamzesi çâk eylesin şu sînemizi

Der-i vefâ bu mefâtihle olur meftûh (G. 14/ 6)

(Bırak kıyabakışının kılıcı göğsümüzü parçalasın. Vefa kapısı bu anahtarlarla açılır.)

O kıyabakıştan pek çok şey öğrenilir:

Kitâb-1 hüsnünü ders itmede dil-i mecrûh

Hutût-1 gamzen ile sînem olalı meşrûh (G. 14/1)

(Kıyabakışının çizgileriyle göğsüm parça parça olalı, yaralı gönül senin güzellik kitabını öğrenmekte.)

Ne kadar gizlenmeye çalışılırsa da aşk kendini belli eder:

Ne rütbe ketme çalışdımsa âteş-i '1şkı

'Atâ o ser-keşe dûd-1 dilimden oldı 'ayân (G. 61/5)

Âşığın ruh hali, sevgilinin tavrına, tarzına göre değişir:

Yâ Rab n'olurdu hâlet-i ma'kûs-1 'âşıkân

Mir'ât-veş görünse cemâli nikâbdan (G. 59/4)

(Ey Allah'ım! Sevgilinin yüzü ayna gibi örtüden görünseydi acaba âşıkların talihsiz halleri ne olurdu?)

\section{Rakib:}

Murdardir:

Görüp rakîbe nigâhın telh-kâm oldum

Yakışmaz idi bu şîrîn-edâ o murdâra (G. 70/4)

(Rakibe bakışını görünce üzüldüm. Bu tatlı tavır, o murdara hiç layık değil.)

Kelptir:

Olmasaydı bu gice ol şeh ile kelb rakîb

Bezm-i meh-tâba iderdik anı elbet tergîb (G. 9/1)

(O padişah ile köpek rakip olmasaydı, bu gece elbette mehtap meclisine onu heveslendirirdik!)

Şair-şiir:

Gerçek şair çok azdır: 
Felekde gerçi sühandân hayli çok lîkîn

Bir iki belki çıar sadr-1 beyt-i şi're mukîm (K.1 /51)

(Her ne kadar felekte söz söylemeyi bilen kişi çok ise de şiir evinin başköşesinde oturan ancak bir iki tane belki çıkar.)

Sevgilinin etkili olması, şairin hayali sayesindedir:

Pertev-endâz-1 zemîn olmaz serâpâ şîvesi

Mû-miyânın itmese bir şâ‘ir-i mâhir hayâl (G. 51/4)

(Bir maharetli şair onun kıl gibi belini hayal etmeseydi, onun edas1, yeryüzünü baştanbaşa nurlandırmazdı.)

Şairin yazdıkları dostlarına ilham olur:

Yârân-1 nazma old1 'Atâ bir nev ihtirâ'

Bu nüsha-i latîfe ki inşâdayız yine (G. 69/5)

(Ey Atâ! Yazmakta olduğumuz bu latif nüsha nedeniyle nazım dostlarına yeni bir icat oldu.)

Şiirin değeri düştükçe düşmüştür:

Yek câm-1 meye pîr-i mugan almiyor eş'âr

Elfâz-1 hüner şimdi ‘Atâ bir pula düşdü (G. 73/5)

(Meyhaneci tek bir içki kadehine şiir almıyor. Ey Atâ! Şimdi hünerli sözler bir pula (kadar) düştü.)

Şair, daima yeni şeyler söylemek ister:

Zemîn-i tâzeye çeksem hayâl edip kalemi

'Atâ ne çeşme-i hayvân iderdim istihrâc (G. 13/6)

(Ey Atâ! Hayal kurup kalemi taze yere çeksem, kim bilir ne hayat çeşmesi çıkarmış olurdum.)

Şiirleri başka şairlere de yol gösterebilir:

Vasf-1 hüsn-i yâr içün bu şi'r-i rengînim 'Atâ

Oldu levh-i hâtır-1 yârânda ferhunde-fâl (G. 52/5)

(Ey Atâ! Sevgilinin güzelliğini vasf etmek için yazdığım bu latif şiirim, dostların gönül levhasında uğurlu oldu.)

Şairler şiir geliniyle evlenmek için hayli bedel öderler: 
Vildan S. Coşkun

'Atâ nükûd-1 midâdı döküp ricâl-i kalem

Tezevvüc eyledi ebkâr-1 nazma hamd u sipâs (G. 39/5)

(Ey Atâ! Hamd ve şükür olsun ki kalem erleri çokça para döküp şiir bekârlarıyla evlendi.)

Ol şâ'ir-i mâhir benim vasfında hem kâsir benim

Bir pâdişâhın kim ola remzi ‘ayân Furkân'dan (T. 4/8)

(Ben mahir bir şairim ve işareti Kur'an'da açık olan bir padişahı övmekte eksik kalan da benim)

\section{Diğer şairler:}

Divan'da Atâ'nın tahmis yazdığı şair Kânî dışında divan şairlerinden, Nâbî, Nedim ve Fehîm anılır; ayrıca Sâbit ve Bâkî'ye cinas yoluyla gönderme yapılır:

Nâbî:

Şimdi bilmezler 'Atâ kadrimiz ebnâ-yı zamân

'Asrımzda n'ola Nâbî kadar üstâd olsak (G. 48/5)

(Ey Atâ! Biz kendi çağımızda Nabi gibi üstat olsaydık da zamanın çocukları kadrimizi bilmiyorlar.)

Nedîm ve Fehîm

Unuttu gitti sözün de selef zamânında

'Ademde sâbit ü bâkî olup Nedîm ü Fehîm (K. 1/50)

(Nedîm ve Fehîm yoklukta sâbit ve bâkî (yani kalıcı) olup zamanında öncekiler de (onların) sözlerini unuttu gittiler.)

\section{Tarih-mitoloji:}

İki meşhur nakkaş Mâni vü Behzâd:

Yine itmekde felek sûretimiz seng-i mezâr

Nakşın almakda anın Mâni vü Bihzâd olsak (G. 48/)

(Felek yine yolumuzu, tarzımızı mezar taşı gibi yapmakta. Biz de onun örneğini almada Bihzâd ve Mâni olsak!)

Ferhâd-Şîrîn: 
Dimâğ-1 câna ne işrâb ider o Şîrîn-fem

Sorulsa la'1-i lebinden fesâne-i Ferhâd (G. 15/3)

(Şayet sevgilinin dudağının şarabından Ferhad'ın efsanesi sual edilseydi, acaba can dimağına o şirin ağızlı ne içirirdi (anlatırdı)?)

Hülâgû Hân:

Sevgili, tarihteki yağmacı komutana benzetilir:

Bir kirişmeyle alıp hâtır-1 vîrân şehri

Anı ma' mûre-i 'aşk etti Hülâgû Hân'ım (Beyit 15)

(Hülâgû Hân ${ }^{16}$ (olan sevgilim) bir kaş göz etmeyle viran gönül şehrini aldı ve onu aşkla imar etti.)

\section{Musıki, Meclis, Meyhane:}

Mutrib:

Mutrib ol sünbüle dâir sözü alma diline

Tîz-meşrebdir o dem-sâz tokunma teline ( G. 67/1)

(Ey sazende! O sünbüle benzeyen sevgiliye dair tek bir sözü bile ağzına alma sakın! O arkadaş acelecidir, aman teline dokunma!)

Makamlar:

Pûselik aradığın perdedir ammâ mutrıb

Bu muhalifçe düşer vech-i Hüseyin koluna (G. 67/3)

(Ey sazende! Buselik aradığın perde olmakla birlikte Hüseyin kolu tarafına muhalif kalır. $)^{17}$

16 Cengiz Han'ın torunu ve İlhanlı devleti'nin kurucusu olup yaptığı kanlı savaşlarla meşhurdur. (ö. 1265). Bkz. Abdülkadir Yuvalı (1998), "Hülâgû", TDVİA, c. 18, s. 473. Divan şiirinde, yağma ve çapulları ile anılır. Bkz. İskender Pala, Ansiklopedik Divan Şiiri Sözlüğü, İstanbul Kapı Yayınları, s. 216.

17 Çalgıcıya seslenip aradığın perde buselik (öpmelik) bir perdedir ama bu, vech-i hüseyn usulüne aykırı düşecek bir durumdur diyor şair. Şânîzâde musiki bilgisini bu beyitte kullanarak iki makamın birbirine aykırı düştüğünü ifade etmektedir. Buselik ve vech-i Hüseynî iki musiki terimidir. Hüseyni aşirân makamının diğer adı vech-i hüseynîdir. Hüseynî makamından âşirân'a çeşitli usullerle tam bir seyir yapılınca buna vech-i hüseynî denir. Seyri inici olan bu makamda buselik yer almaz. Buselik 
Vildan S. Coşkun

Sâkî’nin güzelliği meclise yansır:

Ruh-1 sâkîyi gör bu devr-i meyde

Ne sûret virdi mir'âtü's-safâya (G. 68/2)

(Bu içki devrinde (döndürmede, çağında) sakinin yanağının mutluluk aynasına ne şekilde yansıdığını görmelisin!)

Mecliste sınır tanımadan eğlenilir:

İdelim meclisde yağmâ-yı metâ'-1 hüsn ü ân

Hânedân-1 fitnede zîrâ ki var bir ihtilâl (G. 51/3)

(Güzellik ve cazibe malını mecliste yağma edelim. Çünkü fitne sülalesinde bir karışıklık var gibi.)

Mecliste sevgili olmayınca oranın tadı olmaz:

Açılmaz 'ayş ile dil seyr ile olmaz gönül hurrem

Meger ol yâr ile meclisde sâkî-veş süre bir dem (G. 57/1)

(Gönül mecliste tıpkı saki gibi, o sevgiliyle hoş vakit geçirmediği sürece (veya) içki içmediği sürece zevk ve safa ile açılmayacak ve gezmekle mutlu olmayacak.)

\section{Tabâbet (Hastalıklar ve çareleri):}

Uçuk-merhem:

Tabîbâ gerdenin emdir ki dâğ-1 derde şâfî‘dür

Olur teb-hâledâr-1 hasrete kâfûrdan merhem (G. 54/3)

(Ey tabip gerdanını emmeye izin ver. (Gerdanın) hastalık yarasına şifa olacak (bir ilaçtır). (Zira, hasret uçuğuna kâfurdan merhem yapilır.)

Uçuk:

Alma dehâna sorma o bintü'l-'ineb ${ }^{18}$ lebi

Tebhâle-i zamîr-i ‘Atâ âşikâr olur (G. 29/6)

olursa o makam vech-i hüseynî olmaz. Bu nedenle Daha geniş bilgi için bkz. İsmail Hakkı Özkan, Türk Musıkisi Nazariyatı ve Usulleri Kudüm Velveleleri, Ötüken İstanbul 1998, s. 156-62.

18 Tenkitli metinde Beytü'l-ineb yazılmıştır. Bkz. Adviye Rabia Çipiloğlu., a.g.e., s. 129. 
(O üzüm kızı dudağı ağıza alıp emme! (Yoksa) Atâ'nın gizli uçuğu ortaya çıkar.)

Merhem-i kâfûrî:

Merhem-i kâfûr-1 gerdendir ciger-pârem garaz

Yohsa dâğ-1 deşne-i nâzında bir dil-hâhdır (G. 27/4)

(Ey ciğerparem maksat gerdanın beyaz merheminden başkası değildir! Naz hançerinin yarasında gönlünün çektiği bundan başkasi değildir.)

Sarılık:

Sararttı benzini sevdâ-yı âl-1 ruhsârı

Tebeddüh eyledi sûfîde 'illet-i yerakân (G. 61/2)

(Yanağının kırmızısının sevdası benzini sararttı. Sufide sarılık hastalığı baş gösterdi.)

Çiçek:

Var ise başına kûhun soğuk sular geçti

'Aceb çiçek mi çıkardı nedir bu tavr-ı sakîm (K.1/5)

(Galiba dağın başına soğuk sular döküldü. Acaba çiçek mi çıkardı? Bu hastalıklı tavır da nedir?)

Nasur:

Tabîbâ çek elin zahm-1 derûna çâre bulmazsın

Bu bir nâsûrdur yâra sarılmakla bulur merhem (G. 57/3)

(Ey tabip! Derin yarama çare bulamazsın, elini çek. Bu bir nasur ${ }^{19}$ hastalığıdır. Yarayı sardıkça iyileşir, sevgiliye sarılmakla iyi olur.)

Başağrısi-sirke:

Hall-i hikmetle tabîbâ geçmiyor bu derd-i ser

Rûzigârın serdişinden turş-muhteldir dimâg (Gazel 45/3)

(Ey tabip! Bu baş ağrısı, hikmet sirkesiyle geçmiyor. Rüzgârın sertliğinden şuurum bozuk, bulanıktır.)

19 Göz pınarında, makat çevresinde veya diş etlerinde olan bir hastalık. Bkz. http: / / www.osmanlicaturkce.com/. 
Vildan S. Coşkun

Gönül hastası:

Şu âb-1 hançer-i gamzen devâ-yı sabr amma

Marîz-i derd-i dile la'l-i leblerin emdir (G.128/4)

(Senin şu kıyabakış hançerinin suyu sabrın devasıdır. Ama asıl gönül hastası olanlara (âşık) dudağının kırmızı şarabın (1) emdir emilmesine izin ver veya ilaçtır.)

Kitap ve kütüphaneden bahseder:

Kitâb-1 hüsnünü ders itmede dil-i mecrûh

Hutût-1 gamzen ile sînem olalı meşrûh (G. 14/1)

(Kıyabakışının çizgileriyle göğsüm çizgi çizgi olalı, yaralı gönül senin güzellik kitabını öğrenmekte.)

Kitâb-hâne-i cismi yakardı bîm ü hirâs ${ }^{20}$

Fusûl-i tîr-i nigeh dilde olmasaydı esâs (G. 39/1)

(Eğer (sevgilinin) bakış okunun (açtığı) fasıllar gönülde temel olmuş olmasaydı, korku, beden kütüphanesini yakardı.)

Ders kitapları:

Munlâ okursa medresede metn-i Cevherî

Dendân ile lebinde bize dürr-i Müntekâ (G. 5/4)

(Molla medresede Cevherîn ${ }^{21}$ metnini okursa Dürrü'l-Müntekâ22 (seçkin inci) olan dişler de bizim için sevgilinin dudağındadır.)

\section{Atasözleri ve Deyimler:}

Yâr olup bâr olmamak:

20 Tenkitli metinde bîm-i hirâs okunmuştur. Bkz. Adviye Rabia Çipiloğlu, a.g.e., s. 135.

21 İsmâil b. Hammâd el-Cevherî’nin (ö. 400/1009'dan önce) Arapça sözlüğü. Meşhur olduğundan Osmanlı Medereselerinde çokça okutulurdu. Bkz. Hulusi Kılıç, (2010), “Tâcü'l-Luğa”, 08.01.2020 tarihinde https:/ / islamansiklopedisi.org.tr/tacul-luga sitesinden alındı.

22 Alâüddîn-i Haskefî́nin (ö.1676) Dürrü'l-Müntekâ adlı fıkıh eseri. http: / / www.ehlisunnetbuyukleri.com/Islam-Alimleri-Ansiklopedisi / Detay / ALAUDDIN-I-HASKEFI/3515, Erişim tarihi 08.01.2020. 
Mû-miyân ile kafadâr olup şöyle 'Atâ

Ya'nî bâr olmayalım yâr olalım kâkülüne (G. 67/5)

(Ey Atâ! O kıl belli ile şöyle bir kafadar olalım! Onun kâkülüne yakın olalım da aman engel olmayalım!)

Sakız çiğnemek:

Bir sakız çiynerse de pistân u la'lin bûs için

Nukl-i mey olmaz turunç-1 tâze vü tersâ kızı (G. 75/4)

(Her ne kadar o Hristiyan kızı ve taze turunç (a benzeyen güzel), göğsünü ve dudağını öpmek hususunda biraz lakırdı ettiyse de, içkiye meze olacak cinsten değildir.)

Çokbilmiş:

Nice üftâdeleri hâk-i kadem kılmış imiş

Meger ol fitne-i devrân ne çokbilmiş imiş (G. 42/1)

(Nice âşıkları ayağının toprağı haline getirmişmiş. O asrın fitnesi olan sevgili meğerse ne bilmişmiş.)

İpliği pazara çıkmak:

Gedâ-y1 ${ }^{23}$ tâlib-i vuslat ider mi sabr u sükûn

Figân ki ipliğimiz gayrı çıkdı pâzâra (G. 70/2)

(Vuslat talibinin kölesi sabr edip sükûna erebilir mi? Feryat edelim, artık bütün kusurlarımız anlaşıldı.)

Dile düşmek:

Mahbûb-1 kulûb olduğuçün şeh-i hûbân

Âvâze-i hüsnü gibi dilden dile düşdü (G. 73/3)

(O güzeller padişahı, kalplerin sevgilisi olduğundan güzelliğinin ünü gibi dilden dile düştü.)

Yüz çevirmek:

Gördükçe yüz çevirmede bizden o mâh-rû

Bî-vech vasl-1 yârı temennâdayız yine (G. 69/4)

23 Metnin aslında da geda olan bu kelimenin seda olması manaya daha uygundur. 
(O ay yüzlü güzel bizi gördükçe yüzünü çevirmeye başladı. Biz yüzsüzce yine sevgiliye kavuşmayı temenni ediyoruz.)

\section{Atâ'nın Gazeli ve Şerhi}

Bâde-i câm-1 hakîkatden gönül mestânedir Künbed-i mînâ-yı gerdûn bir tehî peymânedir

Allâh Allâh bir 'imâret var harâbât içre kim Aña nisbetle bu 'âlem hâne-i vîrânedir İtdi mir'ât-1 diliñ pür-jeng 'aks-i mâsivâ Kalbiñ ey sûfî seniñ bir sûret-i put-hânedir Hâne-i dilde yanarken şem'-i '1şkı rûz u şeb Yine göñlüm dâ'imâ ol şu'leye pervânedir

Ehl-i dünyâdır sanırlar sevdiğinden 'âlemi I'tibâr el-Hakk 'Atâ' da vahdet-i Sübhânedir (G. 18)

\section{Nesre Çeviri:}

Bâde-i câm-1 hakîkatden göñül mestânedir Künbed-i mînâ-yı gerdûn bir tehî peymânedir

(Gönül, hakikat kadehinin şarabından sarhoş olmuştur. Feleğin mavi seması (onun için), boş bir kadeh gibidir.)

Allâh Allâh bir 'imâret var harâbât içre kim Aña nisbetle bu 'âlem hâne-i vîrânedir

(Allah Allah, bu yıkıntı içinde öyle bir yapı var ki bu dünya ona nazaran yıkık dökük bir ev gibidir.)

İtdi mir'ât-1 diliñ pür-jeng 'aks-i mâsivâ

Kalbiñ ey sûfî seniñ bir sûret-i put-hânedir

(Masivanın yansısı senin gönül aynanı tozlandırmış. Ey sûfî! Senin kalbin bir puthane resmi gibidir.)

Hâne-i dilde yanarken şem'-i '1şkı rûz u şeb

Yine gönlüm dâ'imâ ol şu'leye pervânedir

( $\mathrm{O}^{\prime}$ nun aşk mumu gönül evinde gece gündüz (durmadan) yanarken gönlüm yine o ışığa daima pervane olmuştur.) 
Ehl-i dünyâdır sanırlar sevdiğinden 'âlemi

İ'tibâr el-Hakk 'Atâ' da vahdet-i Sübhânedir (G. 18)

(Atâ dünyayı sevdiği için dünyaya düşkündür (dünyalık) sanırlar. Oysaki onun itibarı Sübhân'ın birliğinedir.)

Şerh:

Tasavvufî remizlerle yoğrulmuş olan bu yek ahenk gazelde ilâhî aşktan ve yansımalarından bahsedilmektedir.

1.Beyit: Beyitte gönül, hakikat kadehinin şarabını (ilâhî aşk) içip (manevî olarak) sarhoş olan bir derviş olarak görülmektedir. Tasavvufta hakikat, "zâhirin ardındaki örtülü ve gizli mana, dinî hayatın en yüksek seviyede yaşanarak ilâhî sırlara aşina olunması" ${ }^{24}$ anlamlarına gelir. Bade, mecazen "kadeh" demek olup sufilere göre ruhlar yeryüzüne indirilmeden önce Allah'ın huzurunda, bezm-i elest denen kutsal mecliste toplanarak O'na "Belâ" (evet) demek suretiyle aşk bâdesini içmişlerdir. İnsan ruhu, dünya bă̆larından sıyrılarak ilâhî âleme yani bezm-i eleste dönmek ister. ${ }^{25}$ Bununla beraber ezel meclisinde içilen bu hakikat içkisi, etkisini dünya hayatında da sürdürüp sufinin dünyaya "beden gözü" ile değil "gönül gözü" ile bakmasını sağlar. Bu hal içindeki sufi sarhoşluğun verdiği baş dönmesiyle feleği ve gökyüzünü dönen bir boş bir kadeh gibi görür ve onun (dünyanın) manasızlı̆ııı idrak eder. Beyitte gönül, teşhis yoluyla sarhoş bir insana; felek ise teşbih yoluyla şekil bakımından kadehe benzetilmiştir. Özetle, ezel meclisinde sarhoş olan Hak âşığı, dünyayı anlamsız görür.

2.Beyit: Bu beyitte insanın Allah'ın yeryüzündeki tecellisi olarak önemi ve değerinden bahsedilir. Bu çerçevede insan, sahip olduğu gönlü ile çok değerli bir yapıya (bina) benzetilmiştir. Onu değerli kılan şey, bedeni değil gönlüdür. Çünkü tasavvufi açıdan insanın var olma sebebi olan aşkın merkezi, mutlak yaratıcının tecelli ettiği ve yaratıcıya ulaşmanın en önemli noktası gönüldür.

24 Mehmet Demirci, (1997), "Hakikat", 01.01.2010 tarihinde https:// islamansiklopedisi.org.tr/hakikat\#2-tasavvuf sitesinden alınd1.

25 İrfan Gündüz, (1991), "Bâde”, 11.01.2020 tarihinde https: / / islamansiklopedisi.org.tr/bade sitesinden alınd1. 
Tasavvufta, dünya hayatındaki her şey gibi insan bedeni fâni olduğundan yıkılası bir bina veya bir harabe veya bir viraneye benzetilir. İnsan bedeni de aynı şekildedir. Ancak insanın o harabe bina gibi görünen bedeni içinde öyle mamur bir eser vardır ki o da sağlam ve gösterişli bir binaya benzeyen gönüldür. İçindeki baki aşk ile mamur bir bina gibi olan insan gönlü yanında, âlemde fani olan diğer her şey, viraneler gibi değersiz ve önemsiz kalır. Beyitte açık istiare yoluyla beden harabata, gönül de imarete benzetilmiştir. Âlem ve yıkı ev benzetmesinde ise teşbih-i beliğ bulunmaktadır.

3.Beyit: Allah'ın tecelligahı olduğu, Allah'ın nurunu yansıttığı için tasavvufta gönlün benzetilenlerinden biri de aynadır. Tasavvufta masiva, Hakk'ın dışındaki varlıklara verilen ad olup şehadet âlemi denilen âlem ve bu âlemde Hakk'ın zuhur ettiği yerler (mezâhir) demektir. Buna göre âlem, dünya, dünyadaki her şey, insan, insanın fiilleri, düşünceleri, tasavvur ettikleri ve bilgiler masiva olarak nitelenir. (Çalka-Türk, 2018: 475) Bundan ötürü masiva, sufiyi Allah'tan uzaklaştırma özelliği taşır. İnsanı seyr ü sülûk eğitiminden geçirerek onu 'insan-ı kâmil' mertebesine çıkarmayı hedefleyen tasavvufta eğitim vasıtası gönüldür. (Akbalık, 2013: 22) Bir başka deyişle insan gönül terbiyesi yoluyla kemale erer. Gönlün Allah'ın tecellilerinin yansıdığı ayna görevini yerine getirebilmesi için onun tozdan, kirden, pastan arınmış olması gerekir ki bu da ancak kemale ermesi ile mümkündür. Beyite göre masiva gönül aynasını pas, kir ve toz ile kirlettiğinde onu Allah'tan uzaklaştırmış, O'nun yansımasına mani olmuş olur. Bu durumda Hak'tan ayrılan gönle O'nun dışındaki her şey yerleşmiş ve gönül Hak'kın zıddı olan batıl ile yani putlarla dolmuş olur. Bu durumda gönül, İslam öncesi dönemlerindeki gibi içi putlarla dolu Kâbe'ye benzemiş olur. Allah'ın evinde başka şeyleri barındırmak hele hele inancı bozan putları barındırmak doğru olmayacağından kalpte masiva olmamalı, hatta masivanın yansıması bile ondan uzak olmalıdır. Beyitte şair sufiyi dünya ya bağlanmak karşısında uyarır. Gönül aynaya benzetilerek teşbih-i beliğ yapılmış içinde putlardan bahsederek Kâbe'ye benzetilmek suretiyle kapalı istiare yapilmıştır. 
4.Beyitte gönül, içinde mum yanan bir eve; aşk ise muma benzetilmiştir. Başka bir ifadeyle gönül içinde aşk mumu yanan, aşk mumuyla aydınlanan bir ev olarak düşünülmüştür. Tasavvufta gönül Allah'ın evi kabul edilir. Bunun sebebi Allah'ın müminin gönlünde olmasıdır. Çünkü bir hadis-i kutside rivayet edildiği söylendiği gibi "Kalb Allah'ın arşıdır, yerlere ve göklere sığmayan Allah mümin kulunun kalbine sığmıştır." Beyitte bahsedilen gönül evindeki aşk mumu, ilâhî aşkı temsil eder. İlâhî aşk, fâni değil bâkî olduğundan sürekli yanmaktadır. Beyite göre aşk mumu yandıkça aşı̆̆ın gönlü aşk mumunun etrafında pervane olan, ona kapılan ve onun için kendini feda eden pervane (kelebek) olur. Aşk var olduğu sürece gönül onun için yanıp tutuşacaktır. Gönül ev, aşk mum benzetmesinde teşbih-i beliğg, aşığın pervaneye benzetilmesiyle açı istiare yapılmıştır.

5.Beyit: Yek avaz olan bu gazelde Atâ, bu gazelde son beyitte lafı kendine getirir. Kendisinin dünyayı sevdiğini, bu nedenle dünyaya düşkün olmakla kınandığını söyler. Oysaki gerçekte onun asıl önem verdiği şeyin Sübhân olan Allah'ın birliği olduğunu ifade eder. Kesret olan dünya ile işinin olmadığını, vahdete yöneldiğini söyler. Atâ mahlas beytinde tecrit sanatı yaparak kendini üçüncü bir kişi olarak göstermiştir.

\section{Sonuç}

19. asır, sosyal, siyasal ve ekonomik açıdan olduğu kadar kültürel bağlamda da adeta yeniden yapılanma asrı olmuş klasik Türk edebiyatı da bu dönemde şekil ve muhteva bakımından değişikliklere yönelmiştir. Şânîzâde Mehmed Atâullah Efendi, böyle bir dönemde yetişerek tıp, matematik, astronomi gibi fen bilimlerinin yansıra tarih ve edebiyat alanlarında da eser veren, ayrıca musiki, resim ve hat gibi sanat dallarında da kendini gösteren âlim bir şair olarak karşımızda durmaktadır. Hakkında bilgi veren kaynaklar ve eserleri üzerine yapılan çalışmalar daha çok onun tarihçiliği ve hekimliği etrafında toplanmış sanatı hatta şairliği çok az anılmıştır. Oysa Divan'ı incelendiğinde onun pek çok alanda sahip olduğu bilgi ve beceriler kadar şairliğinin izlerini de burada takip etmenin mümkün olduğu görülecektir. Atâullah Efendi'nin Divan'1 kendinden önceki asırlarda yaşayan şairlerin üsluplarını ve divan 
şiirinin hemen hemen tüm karakteristik konularını içermesi açısindan neredeyse altı yüz yıllık divan şiirinin bir özeti gibidir. Dil, üslup, sanat, konu ve işleyiş bakımlarından Atâ'nın kimi zaman Necâtî, Bâkî, Nâbî, Nedim ve kimi zaman ise mutasavvıf bir şair gibi davrandığı görülmektedir. Bu haliyle Divan'ı, tıp, astronomi, musiki, tarih gibi şairin sahip olduğu pek çok yönü, bazen derin anlamlar bazen ise sade benzetmeler şeklindeki göndermelerle zevkli ve estetik çağrışımlarla yansıtmaktadır. Şairlik yönü ile pek fazla tanınmamış olsa da Divan'ına yeniden ve daha derinlemesine bakıldığında, pek çok ilimle mücehhez bir âlim, bir tabip, bir tarihçi, bir musikişinas, bir mutasavvıf olan Şânîzâde Atâullah Efendi'nin hezârfen bir şair olarak divan şiirinin son halkasını oluşturan zincirde başarıyla yerini almış ve bulunduğu noktada hem konu ve hem de söyleyiş bakımından Osmanlı'nın ilim ve sanatı birleştiren bütüncüllüğü yakalayarak yansıtmayı başarmış olduğu görülecektir. 


\section{Kaynakça}

(1994), Türk Kültüründe Tire [Türk Kültüründe Tire Sempozyumu (I : 1993 : Tire-İzmir)], Yay. haz. Mehmet Şeker, Türkiye Diyanet Vakfi: Ankara.

Akbalık, Esra. (2013), “Yunus Emre'nin Şiirlerinde Gönül İmgesi”, Uluslararası Sosyal Araştırmalar Dergisi The Journal of International Social Research, C. 6 (6), s. 20-28.

“Alaüddün-i Haskefi". 08.01.2020 tarihinde http:/ / www.ehlisunnetbuyukleri.com/Islam-Alimleri-Ansiklopedisi/Detay / ALAUDDIN-I-HASKEFI/3515 sitesinden alındı.

Arslan, Mehmet (2014), “Atâ, Şânî-zâde Mehmed Atâullah Efendi", 1.09.2019. tarihinde http:/ / www.turkedebiyatiisimlersozlugu.com / index.php?sayfa $=$ detay\&detay $=4772$, sitesinden alındi.

Cemaleddin, Mehmed. (2003), Osmanlı Tarih ve Müverrihleri Âyine-i Zürefâ, Haz. Mehmet Arslan, İstanbul: Kitabevi Yayınları.

Çalka, Mehmet Sait, Türk, Fatma. (2018), “Gönül Kavramının Redif Bağlamında Kazandığı Anlamlar", 30.12.2019 tarihinde https: / / dergipark.org.tr/tr/download/ article-file / 609016 sitesinden alınd1.

Çipiloğlu, Adviye Rabia. (2005), Şânîzâde Atâullâh ve Divan'ı, Boğaziçi Üniversitesi Sosyal Bilimler Enstitüsü Yayımlanmamış Yüksek Lisans Tezi, İstanbul.

Davison, R. H. (1995), "Shânî-zâde", EI2 (New Edition), V. IX, (facs. 151-152), Brill: Leiden, s. 303.

Demirci, Mehmet. (1997), “Hakikat”, 01.01 .2010 tarihinde https:/ / islamansiklopedisi.org.tr/hakikat\#2-tasavvuf sitesinden alınd1.

Diriöz, Meserret. (1989), "Divan-1 Şânîzâde", Hekim Şânîzâde Atâullâh (1771-1826), Erciyes Üniversitesi Gevher Nesibe Tip Tarihi Enstitüsü: Kayseri, s. 21-27.

Eldem, Edhem. (2013), “Hayretü'l-Azime, fi intihalati'l- garibe: Voltaire ve Şanizade Mehmed Atâullah Efendi", Toplumsal Tarih, S. 237, s. 18-29. 
Erdoğan, Mehmet. (2016), Şâni-zâde Mehmed Atâullah Efendi (Hayatı, Kişiliği, Eserleri, Etkileri), Eskişehir Osmangazi Üniversitesi Sosyal Bilimler Enstitüsü Yüksek Lisans Tezi, Eskişehir.

Ergun, Sadettin Nüzhet. (1935), Türk Şairleri, C. 2, İstanbul.

Gündüz, İrfan. (1991), "Bâde”, 11.01.2020 tarihinde https:/ / islamansiklopedisi.org.tr/bade sitesinden alındı.

İbnül Emin Mahmut Kemal. (1969), Son Asır Türk Şairleri, C.I, Ankara: Milli Eğitim Bakanlığı,

İsen, Mustafa vd. (2003), Eski Türk Edebiyatı El Kitabı, Grafiker Yayınları: Ankara.

Kahya, Esin. (1989), "Şanizâde Mehmed Ataullah Efendi", Erdem, C.5, s. 847-862.

Kılıç, Hulusi. (2010), “Tâcü'l-Luğa”, 08.01.2020 tarihinde https: / / islamansiklopedisi.org.tr/tacul-luga sitesinden alınd1.

Mehmed Süreyya. (1996), Sicill-i Osmânî I, Yay. Haz. Nuri Akbayar, Eskiyazıdan Aktaran: Seyyid Ali Kahraman, İstanbul: Tarih Vakfı Yurt Yayınları.

Mermer, Ahmet vd. (2015), Eski Türk Edebiyatına Giriş, Ankara: Akçă̆ Yayınları.

Özkan, İsmail Hakkı. (1998), Türk Musıkisi Nazariyatı ve Usulleri Kudüm Velveleleri, İstanbul: Ötüken Yayınları.

Pakalın, Mehmet Zeki. Tarih Deyimleri Ve Terimleri Sözlügüu, 3 C., MEB: Ankara.

Pala, İskender. (2016), Ansiklopedik Divan Şiiri Sözlüğü, İstanbul: Kapı Yayınları.

Solmaz, Süleyman. (2016), “Tasavvufta Ulaşılması Gereken Bir Mertebe: Elfakru Fahri ve Eski Edebiyatımıza Yansımaları A Spiritual State To Reach in Sufi Tradition: Al-Faqr Fakhri", Uluslararası Hacı Bayrâm-ı Velî Sempozyumu Bildiriler Kitabı: 25-26 Mayıs 2016, C. II, s. 115-133.

Uludağ, Süleyman. (2003), “Masiva”, 18.01.2020 tarihinde https: / / islamansiklopedisi.org.tr/masiva sitesinden alınd1.

Uludağ, Süleyman. (2001), “Kalb”, 07.01.2020 tarihinde https:/ / islamansiklopedisi.org.tr/kalb sitesinden alındı. 
Yavuz, Yusuf Şevki. (1991), “Ayne'l Yakîn”, 01.01.2020 tarihinde https:/ / islamansiklopedisi.org.tr/aynel-yakin sitesinden alındi.

Yılmazer, Ziya. (2010), "Şânî-zâde Mehmed Atâullah Efendi", TDVIA, C. 38, s. 334-336.

Yuvalı, Abdülkadir. (1998), “Hülâgû", TDVİA, C. 18, s. 473-475.

Zülfikar, Mükerrem Bedizel. (1991), Tabip Şâni-zâde Mehmed Atâullah Hayatı ve Eserleri, Özel Yayınevi: İstanbul. 